\title{
Working Together to Take Care of the Land: Building Bridges with Traditional Knowledge in the Gwich'in Settlement Area
}

\author{
Wynet Smith
}

\begin{abstract}
Nits'òo nan k'atr'ahnahtyaa ts'àt nits'òo nan kak gwitr'it t'agwahàa'aa geenjit tr'ilee tr'igwähtsii gwizhit yeenoo dài' nits'òo tr'igwiindài' t'atr'ahdahch'aa geenjit ganiinji'tr'adhat. Gwitr'it geenjit tr'iilee tr'igwahtsii dài' juk drin nits'òo gwiidandaii ts'àt yeenoo dài' nits'òo tr'igwiindài' gwit'atrahdahch'aa iisrits'àt geenjit gòo'aih. Canada gwizhit nan sridatr'igwijiinlik aii gwizhit juudin nan tr'ooheendal, nits'òo nan t'atrahdahch'aa ts'àt juudin nan gwits'àt k'agwahaadhat jii sridatr'igwijiinlik gwi'dinehtl'èe' gwizhit geenjit gòo'aih. Gwich'in kaiik'it gwa'àn nits'òo nan k'atr'ahnyahtyaa geenjit tr'iilee tr'ałtsaii gwits'àt duuleh gwiinleii t'atràhdahch'aa. Jii dinehtł'eh gwizhit nits'òo nan k'atr'ahnyahtyaa ts'àt yeenoo dài' nits'òo tr'igwiindài' t'atr'ahdahch'aa giiniidhan geenjit gwidinithitł'oh. Gwiinzii gwitr'it gwiltsaii, gwiinzii gwitr'it gwiltsaii kwaa ts'àt nits'òo gwiinzii gwitr'it gwahahtsaa geenjit chan jii gwizhit gwidinithitł'oh. Gwitr'it t'agwäh'ii kat gat'igiiniidhan kwaa, nits'òo yeenji' gwa'àn uunjit kat gwitr'it t'agwäh'ii ts'àt kaiik'it gwa'àn gwizhit dinjii kat gat'igiiniidhan kwaa jii kat thak gwits'agwighah t'iinch'uh. Nits'òo yeenoo dài' gwitr'it geenjit tr'iilee gugwiłtsaii, kaiik'it gwizhit dinjii kat thak gwizhit giheelyaa, jidii thak gahgwiheedandaii geenjit dinehtł'eh kak nitr'ihee'aa aii geeghee yeenoo dài' nits'òo tr'igwiindài' gwinjik gwiinzii gwitr'it gwahahtsaa geenjit dinehtt'eh tr'ahahtsaa aii ts'àt kaiik'it gwizhit nits'òo gwiidandaii jii kat tthak gwinjik gwiinzii gwitr'it gwahähtsah. Gwitr'it gwahähtsaa geenjit tr'iilee tr'igwähtsii dài' dinjii zhuh kat thak gwizhit giheelyaa geenjit iisrits'àt gwijinchii, jii gwik'iighè' jidìi gahgidandaii, jidìi geenjit ganiinjì'gadhat ts'àt jidìi iisrits'àt guuveenjit gwijiinchii gwinjik gwiinzii gwitr'it gahahtsah.
\end{abstract}

There is great interest in incorporating traditional knowledge into conservation and development planning. It is especially important to try to develop planning and management approaches that actually integrate traditional knowledge and western management systems. In northern Canada, modern comprehensive land claim agree- ments have been negotiated and signed with the intent of transferring lands, rights, and resource management responsibilities. Many important lessons can be derived from the integrated approach to conservation and resource planning undertaken in the Gwich'in Settlement Area. This paper outlines the key management structures and the systematic processes used to try and incorporate Gwich'in traditional knowledge. Successes and failures are highlighted and key strategies and tools are outlined as well. Key barriers included staff resistance, westernscience biases, and community concerns about westernapproaches. Key solutions were the use of culturally appropriate planning tools, full involvement of community groups, the setting of integrated, strategic research agendas, the development of traditional knowledge policies, and the development of other concrete mechanisms for incorporating local values and knowledge. It is necessary to have full involvement of the indigenous people in the design, development and implementation of the planning and management processes so that the entire system is more reflective of their knowledge, worldviews, and priorities.

\section{Correspondence}

Wynet Smith, Political Ecology of Development Research Group, Department of Geography, University of Cambridge, Cambridge CB2 3EN, UNITED KINGDOM.

Tel. $(\mathrm{H}):$ +44 1223506719

wvs20@cam.ac.uk

Ethnobotany Research \& Applications 3:057-065 (2005) 


\section{Introduction}

Traditional knowledge has been "defined as a body of knowledge built up by a group of people throughout generations of living in close contact with nature. It includes a system of classification, a set of empirical observations about the local environment, and a system of self-management that governs resource use" (Johnson 1992). There is now an extensive body of literature that recognizes the importance of traditional knowledge and management systems for biodiversity conservation and resource planning (Brokensha et al. 1980, Freeman \& Carbyn 1988, Klee 1980, Posey 1999, Quansah 2004). A growing portion of this literature highlights the need to create conservation and resource planning approaches that incorporate both western science and traditional knowledge, rather than just incorporating portions of traditional knowledge into western management systems. Berkes (1981) states that the inclusion of indigenous knowledge and native participation in scientific studies is not sufficient but that some hybrid of the two systems is needed. Riewe and Gamble (1988) state that "cooperative management can not simply mean an advisory role for the Native users; rather the users must be fully involved in the design and production of the wildlife management schemes." A form of co-management is needed that effectively recognizes and involves the traditional management system rather than co-opting and dominating it (Feit 1988). Thus the integration of traditional knowledge into conservation and resource planning involves far more than simply documenting knowledge on a plant or animal and including that in an assessment of how to manage the resource. It requires full involvement of the indigenous people in the design, development and implementation of the planning and management processes so that the entire system is more reflective of their knowledge, worldviews, and priorities.

Modern land claim agreements and co-management structures in Northern Canada are an attempt to address indigenous rights and to involve indigenous peoples more fully in conservation and resource decision-making. While these land claims and co-management structures have brought about some gains, there are also a number of challenges and barriers to achieving the goal of an integrated management system. For example, co-management structures do not necessarily result in community involvement and the incorporation of traditional knowledge in decision-making (Arctic Institute of North America 1996, Wolfe-Keddie 1995). Thus, it is essential to explore new planning approaches in order to build bridges with traditional knowledge in an inclusive and coherent manner. Just how this can be done in practical ways, however, has not been clear.

This paper presents a case study in the Gwich'in Settlement Area (GSA) in the Northwest Territories where work was undertaken to design an integrated approach to con- servation and resource planning with full inclusion of traditional knowledge. The GSA provides a context within which this goal would seem to be possible. It is a settled land claim area that has a large indigenous population with established rights and roles in resource management and conservation. This paper discusses the planning framework developed to try and achieve a more integrated approach to management based on the two distinctive worldviews and management systems. The steps taken include: planning approaches focused on incorporating community values and priorities, "ecosystem-based" approaches that more closely resemble traditional systems, full inclusion of local people and traditional knowledge in a much more systematic manner, and an integration of the work of various agencies in order to achieve common goals. This paper also presents the successes and failures and the major barriers, opportunities and strategies for building bridges between traditional knowledge and dominant scientific approaches. The author of this paper was a staff member of the Gwich'in Renewable Resource Board and then the Gwich'in Land and Water Board whose job was to lead development of the framework for planning and management.

\section{The Gwich'in Context}

The GSA is located in northern Canada and is a result of the Gwich'in Comprehensive Land Claim Agreement (the Agreement), which was signed in 1992 (Government of Canada 1992). The Agreement was developed under the Canadian Government's federal policy for the settlement of Aboriginal land claims (Government of Canada 2001). The GSA consists of $57,000 \mathrm{~km} 2$ of land in the Northwest Territories. It includes four communities: Aklavik, Fort McPherson, Inuvik and Tsiigehtchic. The total population of the Gwich'in Settlement Area including Gwich'in beneficiaries, Inuvialuit, Metis and non-indigenous peoples, is approximately 5,100 . There are close to 2,440 Gwich'in beneficiaries, but only about 1,400 Gwich'in live in the area (Government of Canada 2001).

The GSA landscape includes the Mackenzie River Delta, the largest delta in Canada $(12,170 \mathrm{~km} 2)$. It also consists of portions of the Mackenzie Mountains in the south and the Richardson Mountains on its western extent. Boreal forest, arctic tundra and alpine tundra are common vegetation types. Black and white spruce are the most common tree species, with the largest trees concentrated in the Mackenzie Delta and in the river and creek valleys. Wildlife in the area includes caribou (both Porcupine and Bluenose herds), moose, grizzly and black bear, and various furbearers. Fish are found throughout the settlement area and include Broad Whitefish, Lake Whitefish, Lake Trout, Dolly Varden Charr, and Northern Pike (jackfish). The Gwich'in have depended on harvesting of wildlife for their survival for generations and despite major changes in lifestyle in the last century, Gwich'in continue to rely 
heavily on the land and wildlife. Caribou, moose and fish are common food sources. Berries and other plants have been important traditional food sources. Forests are an important source of materials for various uses.

With the signing of the Agreement in 1992, the Gwich'in First Nation acquired 16,264 km2 of land in the Northwest Territories, 4,299 km2 of which includes mineral rights. They also obtained 1,554 km2 of land in the Yukon Territory, although this is not considered part of the GSA and is subject to co-management structures set up by the Yukon Comprehensive Land Claim Agreement. The Gwich'in also obtained $\$ 75$ million over 15 years, guaranteed wildlife harvesting rights, and participation in decision-making bodies dealing with renewable resources, land use planning, environmental impact and assessment review, and land and water regulation (Government of Canada 2001). The general objectives of the Agreement are:

1. To provide for certainty and clarity of rights to ownership and use of land and resources;

2. To recognize and encourage the Gwich'in way of life which is based on the cultural and economic relationship between the Gwich'in and the land;
3. To provide the Gwich'in with wildlife harvesting rights and the right to participate in decision making concerning wildlife harvesting and management;

4. To provide the Gwich'in the right to participate in decision making concerning the use, management and conservation of land, water and resources;

5. To protect and conserve the wildlife and environment of the settlement area for present and future generations. (Government of Canada 1992).

The Agreement provides a new management and regulatory system in the GSA and specifically sets out a number of principles by which planning and management of resources are to be undertaken. A system of cooperative management boards is set out under the umbrella of the Agreement (Table 1). Section 24 sets out the roles and responsibilities of three of the boards: Land Use Planning, Land and Water and the Environmental Impact Review Board. Section 12 describes the roles and responsibilities of the Renewable Resources Board. The Gwich'in Land Use Planning Board's role is to develop and oversee a land use plan for the GSA. The Gwich'in Land and Water Board is responsible for permitting land and water activities in the GSA. The Mackenzie Valley Environmental Impact Review Board is responsible for environmental assess-

\begin{tabular}{|c|c|}
\hline Category & Specific Groups \\
\hline $\begin{array}{l}\text { Co-management boards: bodies comprised } \\
\text { of government and Gwich'in representatives }\end{array}$ & $\begin{array}{ll}\text { - } & \text { Gwich'in Land and Water Board } \\
\text { - } & \text { Gwich'in Renewable Resources Board } \\
\text { - } & \text { Gwich'in Land Use Planning Board } \\
\text { - } & \text { Mackenzie Valley Environmental Impact Review Board } \\
\text { - } & \text { Mackenzie Valley Land and Water Board } \\
\text { - } & \text { Surface Rights Board }\end{array}$ \\
\hline Gwich'in organizations & $\begin{array}{ll}\text { - } & \text { Gwich'in Tribal Council } \\
\text { - } & \text { Gwich'in Land Administration } \\
\text { - } & \text { Gwich'in Designated Organizations } \\
\text { - } & \text { Gwich'in Renewable Resource Councils } \\
\text { - } & \text { Gwich'in Social and Cultural Institute }\end{array}$ \\
\hline Communities and General Public & $\begin{array}{ll}\text { - } & \text { Aklavik } \\
\text { - } & \text { Fort McPherson } \\
\text { - } & \text { Inuvik } \\
\text { - } & \text { Tsiigehtchic }\end{array}$ \\
\hline Government departments and agencies & $\begin{array}{ll}\text { - } & \text { Indian and Northern Affairs Canada } \\
\text { - } & \text { Department of Fisheries and Oceans } \\
\text { - } & \text { Environmental Canada (Canada wildlife Service) } \\
\text { - } & \text { GNWT Department of Education, Culture and Employment } \\
\text { - } & \text { GNitage Canada (Parks Canada) } \\
& \text { and Economic Development }\end{array}$ \\
\hline Other land claim areas & $\begin{array}{ll}\text { - } & \text { Nunavut Boards } \\
\text { - } & \text { Inuvialuit Boards } \\
\text { - } & \text { Sahtu Boards } \\
\text { - } & \text { Yukon Boards }\end{array}$ \\
\hline
\end{tabular}


ments throughout the Mackenzie Valley. The Gwich'in Renewable Resources Board's role is wildlife planning and management. The latter was set up soon after the agreement was implemented by the Canadian Parliament. The former three required the passage of the Mackenzie Valley Resource Management Act, which came into force in 1997, and which sets a broader context for resource management in the Mackenzie Valley. As a result of the delay in the development and implementation of this Act, working groups for the Gwich'in Land Use Planning Board, the Gwich'in Land and Water Board, and the Environmental Impact Review Board were set up to begin preparatory work. The full boards became active at various points between 1998 and 2000.

A number of other groups are also involved in resource management and conservation in the Gwich'in Settlement Area (Table 1), from federal and territorial Government departments that still have ultimate authority over most resources, to community based groups. The federal Government departments include Indian and Northern Affairs, the Department of Fisheries and Oceans and Environment Canada. In terms of the Government of the Northwest Territories (GNWT), both the Department of Resources, Wildlife and Economic Development and the Department of Education, Culture and Employment have important roles to play. Gwich'in organizations include the Gwich'in Tribal Council, the Gwich'in Social and Cultural Institute and the Renewable Resource Councils. The Gwich'in Tribal Council is the political governing body and the Gwich'in organization with the authority for representing the Gwich'in as a nation. After the signing of the Agreement, the Gwich'in Tribal Council set up the Gwich'in Social and Cultural Institute with the mandate of documenting, preserving and promoting Gwich'in culture, language, traditional knowledge and values. The community Renewable Resources Councils are mandated in the Agreement and their role is "to encourage and promote local involvement in conservation, harvesting studies, research and wildlife management in the local community" (Government of Canada 1992).

A coordinated and integrated management approach that involves government and northern residents in setting policy and building management and regulatory processes is essential to achieving the Agreement's objectives. The creation of the boards and community groups did not guarantee inclusion of traditional knowledge and values. The Agreement states that the organizations created to undertake resource management need to work together in an integrated manner. For example, clause 24.1.1 (a) states that "An integrated system of land and water management should apply to the Mackenzie Valley" (Government of Canada 1992). Clause 12.1.1 (f) states that wildlife management is to "integrate planning and management of wildlife and wildlife habitat with the planning and management of all types of land and water use in order to protect wildlife and wildlife habitat" (Government of Canada 1992).

\section{The Planning Approach}

While the Agreement states that integration and coordination are required, it became evident as the boards began their work that what this meant in practice was not clear. The Gwich'in Land and Water Board working group supported the need for the development of a management framework that would allow all groups to coordinate their work and fully involve community members. As stated earlier, they hired the author, who was doing wildlife and forestry planning work for the Gwich'in Renewable Resources Board, to work upon what this integrated planning and management framework would look like and what it would involve.

The author developed a series of background documents on what integrated resource management meant, the context of the claim, and approaches to conservation and resource planning. These set out general principles by which management should proceed and focused on four types of integration:

1. Integration of ecosystem components (basically an ecosystem management approach);

2. Integration/coordination of relevant groups/agencies involved in decision-making;

3. Integration of western science and traditional knowledge in decision-making; and

4. Integration of different values, viewpoints and uses (Smith 1996).

The entire system was described as needing to integrate western science and traditional knowledge. Traditional knowledge was described as a vital component of the overall management framework.

A variety of planning and management approaches were drawn upon to create this new synthesis, including aspects of ecosystem management (Grumbine 1994), integrated resource management approaches (Lang 1986), and community-based ecological planning principles (Aberley 1993). The general rationale behind the overall planning process was to help address the imbalance in the management approaches used historically by Government departments in Northern Canada. A series of workshops were held to see whether the boards and communities were interested in pursuing this work and to ensure that the approach was culturally relevant and appropriate. The set of steps taken to develop the framework were:

- March 1996: Background paper prepared by staff member of the Gwich'in Renewable Resource Board on integrated resource planning and the GSA context.

- April 1996: Various Gwich'in boards and organizations met and agreed to work together on an integrat- 
ed resource management framework, the elements of which would emerge through the planning process.

- $\quad$ April - June 1996: The author was loaned from the Gwich'in Renewable Resource Board to the Gwich'in Land and Water Board working group to develop the planning model.

- June - November 1996: Background papers were prepared. All groups were involved in initial discussions and review of concept and implementation issues in GSA.

- $\quad$ November 18-20, 1996: Initial workshops held in Inuvik. Participants included: co-management board staff (day 1), co-management board members (day 2 ), and Gwich'in organization representatives (day 3).

- November - January 1997: Preparation of Framework outline based on literature and feedback from initial workshops.

- February 1997: Series of participatory community workshops in the four Gwich'in communities to explain the work and obtain community input. "Working together to take care of the land" emerged as a phrase that everyone agreed summarized the process and the intent of the approach.

- February 1997: First meeting of the Integrated Resources Management Committee, set up to oversee involvement and coordination of groups. The Committee consisted of a member of each Gwich'in comanagement board, a Gwich'in Tribal Council representative, and a representative of the Renewable Resources Councils.

- March 1997: A regional workshop was held that included communities, co-management boards, government, and industry. The workshop focused on the management and planning framework for "working together to take care of the land", as well as work on the land use plan. A major summary report was prepared following this workshop which outlined all the recommendations and actions required.

- $\quad$ April - June 1997: Follow-up work on specific projects undertaken by various groups.

- June 1997: Second series of community workshops to develop the nine projects identified during regional workshop.

- Fall 1997: Initial set of projects completed.

- On-going: Development of Traditional Knowledge Policies, Traditional knowledge projects, General planning processes with a strong community participation component.

A number of outreach programs were undertaken throughout this period to ensure that community members had the opportunity to participate and to be informed. Minutes of meetings were written and circulated to all participants with action items and responsible groups/persons clearly identified. A series of articles on the process, decisions made, and next steps were written and printed in a re- gional Gwich'in newspaper, Delta Voices, that went to all beneficiaries.

\section{"Working Together to Take Care of the Land"}

During the series of workshops, participants discussed vision, principles, goals issues and concerns. In discussing the concepts of ecosystem management, integrated resource management, community-based planning, and traditional knowledge, common Gwich'in restatements of these terms emerged, including "take only what you need", "look after the land" and "we shouldn't abuse the land". In the community workshops in February, a consensus emerged among the Gwich'in participants that this planning framework and process were all about "working together to take care of the land". Land here is used in the sense that the Gwich'in use it. It refers to the entire environment, including wildlife, water and air. It refers to the interconnections, the people and a larger worldview. The Gwich'in do not see these as separate; the world cannot be compartmentalized. Thus, the use of the term "land" refers to all of the land, people, wildlife and interconnections (cf. Gwich'in Renewable Resource Board 1997). Communities considered the concepts, translated the "jargon" and expressed a simple, straightforward, yet complex, vision of what was really needed, transforming the entire process so that it became community-driven.

In this transformation, the concepts of what needed to be included in overall planning evolved and grew so they included aspects not usually considered part of traditional resource planning and management. Four general areas were identified as essential to ensuring that the land is managed well and that traditional knowledge is a core part of the system. These components are: development of the general framework, effective communications, information management coordination, and education and training. During the course of the workshops, nine projects were identified as high priority for developing and implementing the system. These were: clarifying roles of all groups and job descriptions for all staff, community radio programs, communication workshops, plain language land claim (Agreement), land claim education workshops, training needs assessment, public speaking courses for youth, traditional knowledge policies, and a common research agenda/plan. Specific products were developed to achieve some of these projects. For example, The Gwich'in Tribal Council developed a plain language version of the Agreement and held a series of educational workshops to explain what the Agreement really means for people. The Gwich'in Land and Water Board staff developed a resource directory so that everyone would know what each group did and who they could contact for more information (Gwich'in Land and Water Board 1997b). Many of these projects were intended to help ensure people could understand and participate in the new system. 


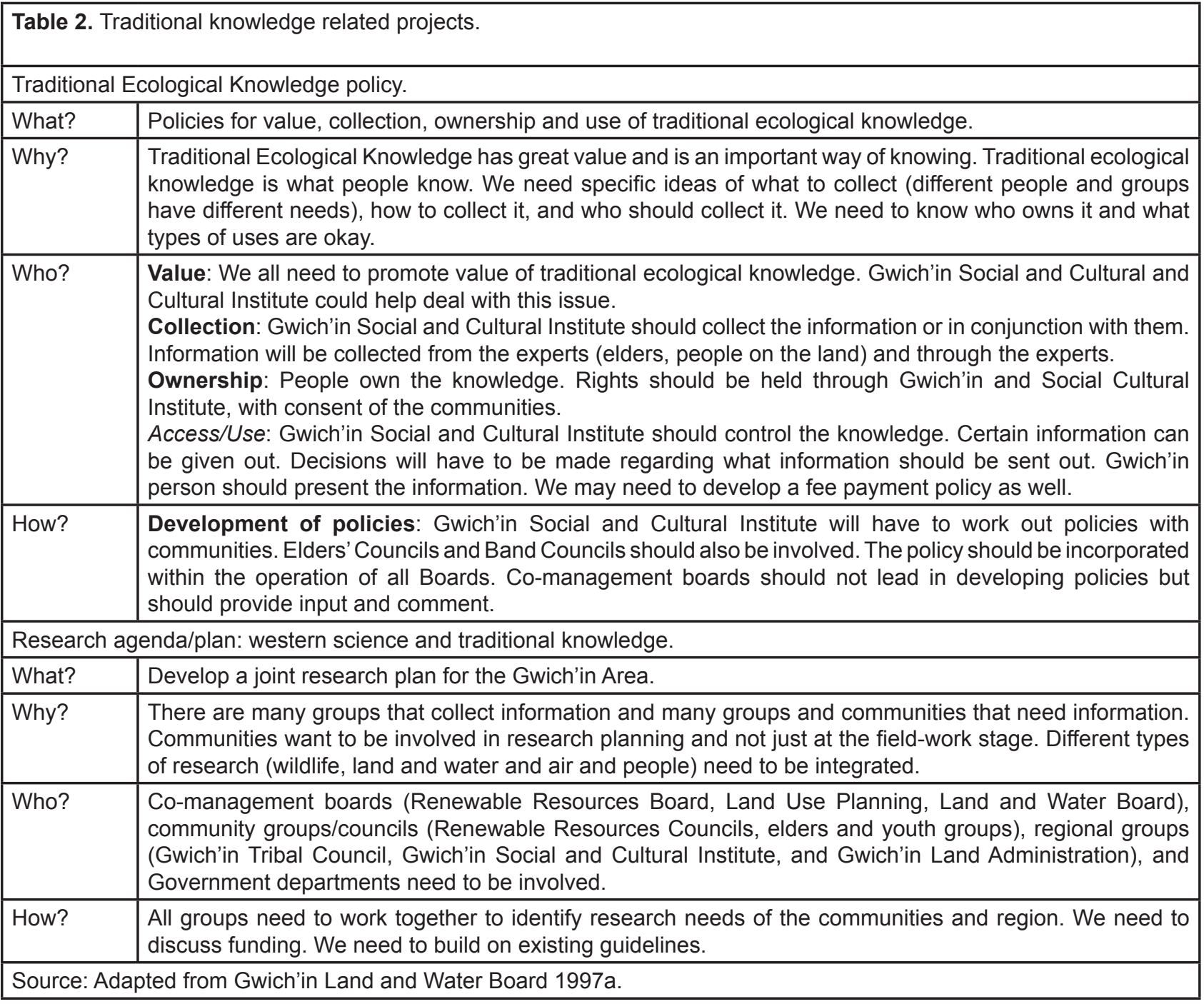

Traditional knowledge was discussed in great depth at most of the workshops. People expressed a strong desire that traditional knowledge be included throughout the decisionmaking process, from research agenda setting to project planning for specific research items. Elders expressed their belief that they had important information to share and contribute and that they needed to be included in any planning work. Bertha Francis, an elder from Fort McPherson stated that "Elders are scientists too" and Sarah McLeod-Firth from Inuvik said that elders are just as strong in their knowledge as any scientist because elders live and practice their knowledge (Gwich'in Land and Water Board 1997a). The Gwich'in have knowledge and observe things in their environment that non-Gwich'in may not (confer Traverse paper). Gwich'in participants stated that it was important, however, that the traditional knowledge remain within the purview of the Gwich'in nation itself, with all ownership of information collected and controlled by the Gwich'in.
Two specific projects relating to traditional knowledge emerged during the regional workshop in March 1997. These were the identification of a need for a traditional knowledge policy and the development of a common research agenda/ plan for traditional knowledge and western science (Table 2). In terms of the research agenda, many people felt that it was important to involve everyone in setting priorities for research, to develop a coordinated strategy for all the groups, and to include both traditional knowledge and western science research. The desire for this strategic research plan was intertwined closely with the idea of developing traditional knowledge policies.

People felt it was important to develop a policy that would address the value, collection, ownership and use of traditional knowledge. The Gwich'in Social and Cultural Institute was identified as the most appropriate agency to collect the information, or that work should be done in cooperation with them. The idea was that the people should own the knowl- 
edge while the Gwich'in Social and Cultural Institute would control access to the information. The Gwich'in Social and Cultural Institute should take the lead on developing the policy, with input from the communities. All groups, including the co-management boards, should then incorporate the policy within their operations.

As a result of the discussions on traditional knowledge, the Gwich'in Tribal Council had the GSCl draft a Gwich'in Traditional Knowledge Policy on their behalf. Another reason for this work was the concern that traditional knowledge work should ensure that the information and products remain the intellectual property of the Gwich'in (cf. Inuit Circumpolar Conference 1997). Prior to these discussions, the Gwich'in Renewable Resource Board had initiated a project that resulted in a database and book, Gwich'in Words about the Land (Gwich'in Renewable Resource Board 1997). There was some concern that these types of projects, if not housed and controlled directly by Gwich'in organizations, would affect both ownership and control (S. Ward, pers. comm.). GTC approved the Traditional Knowledge policy in June 2004 (I. Kritsch, pers. comm.).

During the framework development, a number of elements emerged as essential for a truly integrative approach. These were:

1. Planning strategies and approaches must be based on local values, goals and objectives and not on those of the researchers, managers or Government.

2. Community level participation must be key in all aspects of planning and management. The existence of regional bodies - especially co-management boards - was not seen as a necessary guarantee that local values and knowledge would be included and that the development of appropriate planning strategies.

3. Traditional knowledge studies need to be planned and managed with full involvement of the Gwich'in and ownership of the information and products must rest with the Gwich'in.

4. Integrated research strategies and plans need to be developed that include both traditional knowledge and science studies. The Gwich'in need to be fully involved in the designing of these plans and setting of priorities.

5. Science projects need to be approved by Gwich'in community members and all projects should involve the participation of local researchers.

A number of challenges and obstacles also became evident during the course of this work. Key issues were:

1. Resistance of some co-management staff and government employees toward integrated and participatory, community-based approaches.

2. Difficulty for western science trained individuals to accept other worldview-based approaches to management and conservation planning (cf. Sallenave 1994).
3. Suspicion of local people toward new organizations and people, based on historical imbalances and personal experience.

4. The dangers of a centralized system that some say may just further undermine the traditional systems, ways of knowing and sharing. Clarkson et al. (1992) argue, for example, that centralized decision-making systems and the introduction of modern technologies inherently reduces the ability of indigenous people to retain their own way and creates a dependency and demand for money, equipment and training.

5. There are large differences in scale and education between government, industry and the Gwich'in communities that impact on achieving integrated management. At the community level, there is a very limited number of people to draw on with the education or training needed to provide direction and make informed decisions about conservation and resource planning, as well as other issues. Consequently, this small group of people are often overloaded with work and are at risk of "burning out." Governments and industry have a relatively unlimited source to draw on in comparision to the Gwich'in communities.

\section{Discussion and Conclusion}

Many aspects of the new planning and management regime in the GSA provide a foundation to help achieve the goal of an integrated management system for conservation and resource planning. The Gwich'in have established rights and guaranteed participation in the planning and management processes. Co-management boards are intended to help ensure the indigenous Gwich'in perspective and values are integral to the resource management system. The Gwich'in Land and Water Board undertook to provide the human resource support for the integrated approach because they believed that it was necessary and would help to guarantee Gwich'in participation. The Gwich'in also still have strong connections to the land.

Infrastructure alone, however, does not necessarily ensure appropriate responses. There can be many obstacles that limit progress such as resistance from staff, under-recognition of the value of traditional knowledge, suspicions from some community members, and dangers of co-optation. Developing a system that truly is reflective of different worldviews and ways of knowing is much more complex and has to be truly inclusive. It requires full involvement of the indigenous group in the design, development and implementation of the planning and management processes so that the entire system is more reflective of their knowledge, worldviews, and priorities. It also requires recognition of the differences in available human resources, however, so community members do not burn out from an overload of work. It is important that there is not just a rhetorical nod to the ideas of community participation and Traditional Knowledge; the processes need to 
actually include community members in ways that provide them with the time and resources to participate meaningfully and result in outcomes that truly incorporates their input. Although there were certain pre-dispositions and expectations of what community involvement and the use of traditional knowledge meant in the Gwich'in area when the planning work began, many unexpected elements developed and created a system that was uniquely its own.

The integrated management framework is a vital approach that will help ensure that decisions best reflect Gwich'in views and values, as well as priorities. In the development of the Gwich'in process, it became clear that conservation and resource planning was about much more "managing" the resource". "Working together to take care of the land" is about the land, water, air, people and wildlife. It is not just a plan or a series of reports; it is a process that is about conserving the land in all of its meanings. Interconnections and relationships are a key part of this non-western approach (Taiepa 2004). An integrated approach to traditional knowledge and western management involves a new way of doing things. It is a way that has many challenges but ones that must be undertaken if new, collaborative systems are to be truly achieved and historical injustices addressed.

\section{Acknowledgement}

I would like to thank all the Gwich'in beneficiaries with whom I had the pleasure of working while I lived in the settlement area. I would especially like to thank those elders who were such great sources of inspiration: Bertha Francis, Eliza Greenland, Mary Kendi, the late Johnny Charlie Sr., Robert Alexie Sr. and Charlie Snowshoe Sr. The Gwich'in Land and Water Board members were extremely supportive and I thank them for allowing me to participate in this important work. Colleagues within the Gwich'in comanagement boards and organizations are also acknowledged, especially Brian Ferguson, Bob Simpson, Neida Gonzalez, Shannon Ward and Stephanie Irlbacher Fox. Thom Meredith is thanked for comments on an earlier draft of this paper. Ingrid Kritsch of GSCI and Stephanie Irlbacher Fox both provided some very useful suggestions for improvements on the paper as well. I would like to thank Eleanor Firth of Fort McPherson for providing the Gwich'in translation. I would also like to thank LEAD International for their financial support of my participation in the Building Bridges with Traditional Knowledge conference in May 2001, where I presented this paper.

\section{Literature Cited}

Aberley, D. 1993. Editor of Boundaries of Home: Mapping for Community Empowerment. New Society Publishers, Gabriola Island.
Arctic Institute of North America and Joint Secretariat. 1996. Circumpolar Aboriginal People and Co-Management Practice: Current Issues in Co-Management and Environmental Assessment. Arctic Institute of North America, Calgary.

Berkes, F. 1981. The role of self-regulation in living resources management in the North. Pp 143-160 in Proceedings of the First International Symposium on Renewable Resources and the Economy of the North. Edited by M.M.R. Freeman, Association of Canadian Universities for Northern Studies, Ottawa.

Brokensha, D., D. Warren \& O. Werner. 1980. Editors of Indigenous Knowledge Systems: the Cultural Dimension of Development. University Press of America, Lanham.

Clarkson, L, V. Morrissette \& G. Regallet. 1992. Our Responsibility to the Seventh Generation: Indigenous Peoples and Sustainable Development. International Institute for Sustainable Development, Winnipeg.

Feit, H. 1988. Self-management and state-management: forms of knowing and managing northern wildlife. Pp. 7291 in Traditional Knowledge and Renewable Resource Management in Northern Regions. Occasional Publication Number 23. Edited by M.M.R. Freeman \& L.N. Carbyn. Boreal Institute for Northern Studies, University of Alberta. A joint publication of the IUCN Commission on Ecology and the Boreal Institute for Northern Studies, Edmonton.

Freeman, M.M.R. \& L.N. Carbyn. 1988. Editors of Traditional Knowledge and Renewable Resource Management in Northern Regions. Occasional Publication Number 23. Boreal Institute for Northern Studies, University of Alberta. A joint publication of the IUCN Commission on Ecology and the Boreal Institute for Northern Studies, Edmonton.

Government of Canada. 2001. Comprehensive Claims Policy and Status of Claims. Department of Indian and Northern Affairs Canada, Ottawa.

Government of Canada. 1992. Gwich'in Comprehensive Land Claim Agreement. Department of Indian and Northern Affairs Canada, Ottawa.

Grumbine, R.E. 1994. What is ecosystem management. Conservation Biology 8:27-38.

Gwich'in Land Use Planning Board. 1999. Draft Gwich'in land Use Plan. Gwich'in Land Use Planning Board, Inuvik.

Gwich'in Renewable Resource Board. 1997. Gwich'in Words about the Land. Gwich'in Renewable Resource Board, Inuvik. 


\section{W. Smith - Traditional Knowledge in the Gwich'in Settlement Area}

Gwich'in Land and Water Board. 1997a. Integrated Resource Management and Land Use Planning Workshop Report. Gwich'in Land and Water Board, Inuvik, NWT. Gwich'in Land and Water Board. 1997b. Phone Book for the Gwich'in Settlement Area. Gwich'in Land and Water Board, Inuvik.

Inuit Circumpolar Conference and Fisheries Joint Management Committee. 1997. A Seminar on Two Ways of Knowing: Indigenous and Scientific Knowledge. Inuit Circumpolar Conference and Fisheries Joint Management Committee, Inuvik.

Johnson, M. 1992. Lore: Capturing Traditional Environmental Knowledge. International Development Research Centre, Ottawa.

Klee, G. 1980. World Systems of Traditional Resource Management. V. Winston and Sons, New York.

Lang, R. 1986. Editor of Integrated Approaches to Resource Planning and Management. University of Calgary Press, Calgary.

Posey, D.C. 1999. Editor of Cultural and Spiritual Values of Biodiversity. United Nations Environment Programme, Intermediate Technology Publications, London.

Quansah, N. 2004. The Neglected Key to Successful Biodiversity Conservation and Appropriate Development: Iocal traditional knowledge. Ethnobotany Research and Applications 2:89-91

Riewe, R. \& L. Gamble. 1988. The Inuit and wildlife management today. Pp. 31-37 in Traditional Knowledge and Renewable Resource Management in Northern Regions. Occasional Publication Number 23. Edited by M.M.R. Freeman \& L.N. Carbyn. Boreal Institute for Northern Studies, University of Alberta. A joint publication of the IUCN Commission on Ecology and the Boreal Institute for Northern Studies, Edmonton.

Salleneve, J. 1994. Giving traditional knowledge its rightful place in environmental impact assessment. Northern Perspectives 22:16-19.

Smith, W. 1996. Background Paper \# 2: Defining Integrated Resource Management. Unpublished discussion paper, Gwich'in Land and Water Board, Inuvik.

Smith W. September 1997. Community workshops on "working together to take care of the land". Pg. 7 in Delta Voices, Inuvik.

Taiepa, T. 2004. Weaving Our Stories Worldwide: An indigenous approach to global economics and ecology. Ethnobotany Research and Applications 2:93-99.
Traverse, M. \& R. Baydack. 2005. Observing Subtleties: Traditional Knowledge and Optimal Water Management of Lake St. Martin. Ethnobotany Research and Applications 3:51-55.

Wolfe-Keddie, J. 1995. First Nations: sovereignty and land claims. Pp. 55-79 in Resource and Environmental Management in Canada: Addressing Conflict and Uncertainty. Edited by B. Mitchell. Oxford University Press, Toronto. 
